\title{
ポリビニルアルコール繊維の反応性染料 による染色
}

\author{
名古屋工業大学緎維高分子工学科 後藤 共子 - 長 野正 满* \\ DYEABILITY OF POLYVINYL ALCOHOL (PVA) FIBER \\ WITH REACTIVE DYES
}

By Tomoko Goto and Masamitsu Nagano

(Nagoya Institute of Technology, Department of Fiber and

Polymer Technology, Gokiso-cho, Showa-ku, Nagoya)

\begin{abstract}
In order to clarify the dyeing mechanism of PVA fiber with reactive dyes, the effect of the amorphous state on the dyeability of reactive dyes was studied. Two reactive dyes were synthesized and the experiments on the dyeabilities were carried out in the homogeneous (solution reaction I) and heterogeneous systems (solid state reaction II).

The results were as follow,

A) The effect of substituent of 1,3,5-triazine ring on the rate of the reaction of PVA with reactive dyes depended on its electron density.

B) The reaction rate of 11 was very slow comparing with I and it was considered that the diffusion of dyes into PVA fiber is determined by the reactivity of PVA fiber because of dye aggregation.

C) The dyeability of PVA fiber depended on the degree of the crystallinity and the orientation. The reaction did not occur at the degrees of crystallinity above $50 \%$ and this dyeability increased with the chemical and mechanical treatment of PVA fiber.

It was considered that the causes of this poor dyeability of PVA fiber is related to the surface structure of the fibers and the hydrogen bonding of PVA molecules.

(Received July 6, 1973)
\end{abstract}

\section{1. 緒 言}

漞水性紻維に対する反応性染料の染着反応機構の研究 は数多〈なされているがロ, 染色機構が不均一反応で行 われるため, 繊維の固体構造, 染料の搪散, 競争反応で ある染料の加水分解反応などが複雑に関与し，系統的な 研究はあまりなされていない。さらに，聿験的に一般の 反応性染料の染色では反应性の尺度として固着率が使用 されているが，この固着率は抽出溶㓮の種類によって大 きく異なり゙，末反応染料拉よび染料加水分解物が完全 に除去されているかが非常に疑わしい。

一般の高分子反応においても反応生成物の精製には再 沈殿法をくり返して行うか, 適当な溶凨が見当らない場 合は，交互抽出法によって長期間抽出を行なっている ${ }^{8)}$ 。

\section{，現在の所属：東京家政大学; 東京都板橋区加賀町} 1-18-1

Present addres: College of Tokyo Kase; Kaga-cho 1-18-1, Itabashi Tokyo Japan.
反応性染料の染色で洗浄を十分に行ら程度にお心て固 着率を求め，反応性を議諭することには柔問がある。著 者らは, 先に染色の行われる高分子の非晶領域を, 溶液 状悲に類似すると仮定して 2 級水酸基をもつポリビニル アルュール(以下PVAと記す)と 2 - 置換-4-アミ， -6ークロルー1,3,5-トリアシンの均一系反応を行いそ の反応機搆掞よびトリアジン環につく各種の置換基の影 響について報告しだ〉。本研究は非晶領域の質的な变化 が反応性染料との反応性に，いかに影響するかを検討す るため，PVAの状態を浴液状態から固体状態掞よび各 種の固体構造を有するものと変化させ，合成トリアジン系 反応染料と反応を行い染料の反応性と瀻維の固体構造と の関係支検討し親水性絨維に対する反応性染料の染着反 応機構への固体構造の影響を類推することを目的とした。

\section{2. 実験}

2.1. 試料

2.1.1 PVA 試料 
溶液反应（以下均一系反応とする）に用いた PVA 試

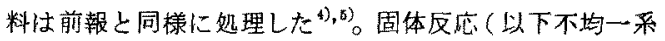
反応とする）には湿式紡系法による紡系直後の1.5デニ 一心の㵶維を氷水括よびィタノールで洗浄し，硫酸ナト リウムを除去して㝬験に用いた。

払散係数測定のために次のような PVAフムルムを用 いた。すなわち均一系反底に用いたと同一PVAの0.5\% 水溶液をがラス板上に流出し， $20^{\circ} \mathrm{C}, 60 \%$ R.H の恒温 佰湿中で一笪夜放䈯して㕌さ10 0 のフィルムとした。

PVAの固体構造を变化させるため瀻維およびフィル 厶支真空䩪燥器中 $140^{\circ} \mathrm{C}$ から $180^{\circ} \mathrm{C}$ まで各温度で 30 分

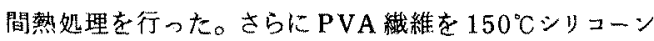
・オイル中にて熱延伸を行い配向度を变化させた。

\section{1 .2 反店性染料の合成}

次に示子染料を山頼ら”の方法にて合成した。すなるち 等モルの2-アミノ-4,6-ジクロル-1,3,5-トリアジ

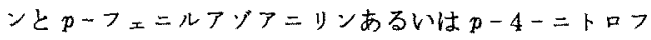
xニルアゾアニリンをアセトン $40^{\circ} \mathrm{C}$ 中にて 4 時間反応さ せた。

得られた下記の染料(1) は反応後シオササンに溶解し 水に沈毁させて精製をくり返した。染粘（2）はアセトン に溶解し，水に沈殿させて精製した。得られた精製物の I Rスベクトルは染料の吸収の外に $1,650 \mathrm{~cm}^{-1}, 810$ $\mathrm{cm}^{-1}$ にトリアシンン環にもとづく新しい吸取が見出され た。差動熱量計による融点は染料 (1) $231^{\circ} \mathrm{C}$, 染料 (2) け $212^{\circ} \mathrm{C}$ である。

ここで $\lambda_{\max }$ は最大吸収波長，もは分子吸光係数でいず れもジメチルスルホキシド(以下DMSOと記す)中の値 である。<smiles>Nc1nc(Cl)nc(Nc2ccc(N=Nc3ccccc3)cc2)n1</smiles>

\section{Dye $1 \lambda_{\max } 376 \mathrm{~mm}$}

$\varepsilon=1.60 \times 10^{4} \mathrm{l} / \mathrm{mol} \cdot \mathrm{cm}$<smiles>Nc1nc(Cl)nc(Nc2ccc(N=Nc3ccc([N+](=O)[O-])cc3)cc2)n1</smiles>

Dye $2 \lambda_{\max } 470 \mathrm{~mm}$

$\varepsilon=1.56 \times 10^{4} \mathrm{l} / \mathrm{mol} \cdot \mathrm{cm}$

\subsection{PVA ᄃ反応性染料の反応}

2.2.1 均一系反应

$0.5 \mathrm{~g}$ のPVAを溶解したDMSO容液 $110 \mathrm{ml} 5 \mathrm{~N}$ 水酸化ナトりウA水溶液 $10 \mathrm{ml}$ を加え，さらに $10 \mathrm{~g}$ の染 料を溶かしたDMSO 澹液 $80 \mathrm{ml}$ を加え，窒素気流中で
各温度，時間で反応させたのち、ジオキサンーフセトン 混合液中に投じて沈殿させ，な执沈殷物を办洗したのち， DMSOとアセトンで再沈潪をくり返して精製した。

2.2.2 不均一系反応

$0.0125 \mathrm{~g} の$ PVA 瀻維をDMSOージオキサン $(1: 1)$ の混合液 $5.5 \mathrm{ml}$ 中に入れ，5 $\mathrm{N}-\mathrm{NaOH}$ 水溶液 $0.5 \mathrm{ml}$ 索 加充， $0.5 \mathrm{~g}$ の染料のDMSO-ジオキサン(1:1) 混合 溶液 $4 \mathrm{cc}$ 追加 L, 減王封管したのち, 各種温度で各時 間反応させ，前項と同様に精製した。

\subsection{3 反店率の測定}

従来PVAと反応性染料との結合量を可視吸収スペク トルから求める万法が行われているがフ，著者らは反応 後のポリビニルアルコール反応生成物を錠剂法により赤 外吸收スペタトルによってFig.1のように求めた。すな

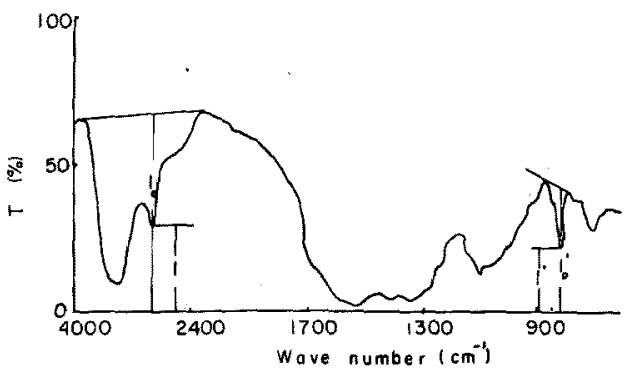

Fig. 1 IR spectrum of a PVA derivative

わ萠報 ${ }^{2}$ と同様にメチル基にもとづく $2,900 \mathrm{~cm}^{-1}$ と卜 リアシンン環の吸収 $810 \mathrm{~cm}^{-1}$ の吸光度比をとり，光学密 度を $\log \left(I^{\prime} I_{0}^{\prime}\right) / \log \left(I / I_{0}\right)$ として，この光学密度と炭 素，䇪素の元素分析值から算出した学換度との関俰曲 線 ${ }^{2)}$ を求め，この検量線加ら反应を睻した。ここで $I ， I_{0}^{\prime} ， I ， I_{0}$ を Fig.1のごとく引いた。反応生成物を直接 取り出して反蜶を測定しているため，初期反底に扔い ては，染料の加水分解反応は考慮にいれずに取り报っ た。

\section{3 拓散係数の測定}

関戸 ${ }^{8)}$ らの方法に準じてフィルム巻層法によって拡散 係数安測定した。巻層は $20^{\circ} \mathrm{C} ， 60 \% \mathrm{RH}$ 中でガラ㐅板

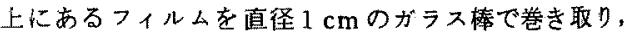

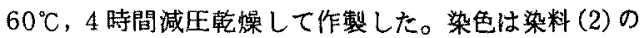

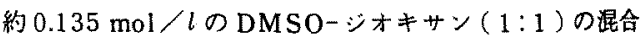
溶液中で浴比 4,000 倍(上記 $(2.2 .2)$ と同一浴比)に て一定温度，一定時間行なった。染色後巻層を開いてフ イルムを乾燥し，各層から $2 \times 3 \mathrm{~cm}$ 切片をとり，DM SO 澹液に溶解させて吸光度を測定した。濃度分布曲繶 はセルロースに対する直接染料の抎散と同様な曲線を示 し，劝かけの桩散係数の計算は関戸，松井”らの方法て 
行った。

$\mathrm{NaOH}$ 含まないこの搪散実験の系では，染料の加水 分解物が染色後含まないことを染色後の染料の I R スペ クトルから確諗したので，この払散実験では染料の加水 分解を無視して扱った。

\section{3. 結果及び考察}

\section{1 均一系反店}

DMSO 溶液中 $60^{\circ} \mathrm{C}$ C゙ PVA と染料との反応率時間曲 線をFig.2に示す。前報で住PVAと 2-埴換ー4ーフミ

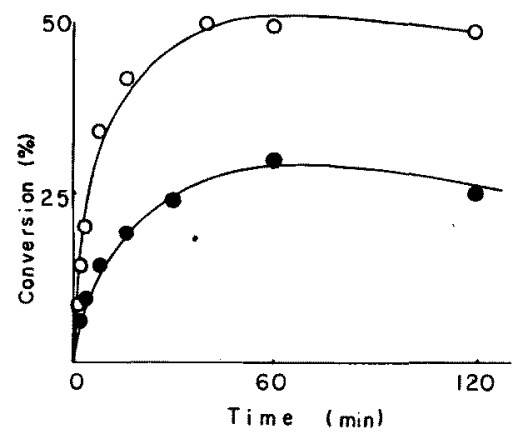

Fig. 2 Relation between conversion and time in the reaction of PVA with dyes

- dye I Odye II at $60^{\circ} \mathrm{C}$

ノ-6-クロロ-1,3,5-トリアジン( SADT) とのDM SO中の均一反応速度はPVAとSADTの各濃度に比 例し, $\mathrm{NaOH}$ 濃度がPVA濃度に近い濃度域では $\mathrm{Na}$ OH浱度にも比例する。さらにPVAとSADTとの反沦 では近似的に，反応速度定数と $m-\sigma$ との間にHa mmett 則方遒用され， $\rho=+2.8$ と求められた。この場合の染料 との反応性も同様に，反応は比較的容易に進み，最高反 他量俚染料 (2)に対して $50 \%$ ，染料（1）に対して $30 \%$ であり，さらに染料 (2) が染料 (1)よりも反応性が速い。 この相違は染料 (2) のニトロ基がフェニルアソペンゼン 罡をかいしてトリフシン環の電子密度を小さくし, 活性 クロル基を離れやすくしているためと考えられる。

最高反応量をさらに上げるため一度反応させた PVA 誘導体を、同一条件でさらに反応を試みても反応は進行 しなかった。これは未反応のPVAの水酸基と反仙した PVAの置換基との間に平衡関係があること，さらに染 料の加水分解，染料分子の隣接による立体障害，また Hildebrand ${ }^{\mathfrak{2})}$ の指摘するように，一度反店した生成物 が過㮃の水酸基によって分解するという原因によるため と考えられる。反応初期における初速度 $k_{0}$ を各温度につ いて求めArrhenius の式にあてはめると Fig. 3 の点線 のごとくになり活性化ェネルギEを求めると染料 (1)に

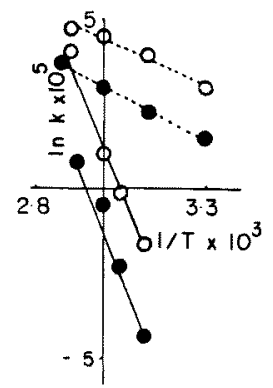

Fig. 3 Arrhenius plot for the reaction of dyes for PVA - dye I Odye II

-.---reaction in homogeneous system

- reaction in heterogeneous system

対しては $10.5 \mathrm{kcal} / \mathrm{mol}$ ，染料（2）に対しては $8.3 \mathrm{kcal}$ $/ \mathrm{mol}$ が得られ，前報の反応と同程度の值を示した。

以上均一容解反応をPVAの非晶領域のモデルと考え てその反珄を検討してきたが，さらに非晶領域の中で PVAの水酸基が会合している場合は，に゙のようになる かを倹討するため，PVAのDM SC溶液中にPVAの非 溶媒であるシオオキサを添加して反应を行った。反応は 溶媒をジオキサン混合液として他の反応条件を 2.2 .1 と同 一で行い $60^{\circ} \mathrm{C}$ での初速度をDMSC 溶液へのジオキサン の泚合量に対してプロットしたものをFig.4に示す。困か

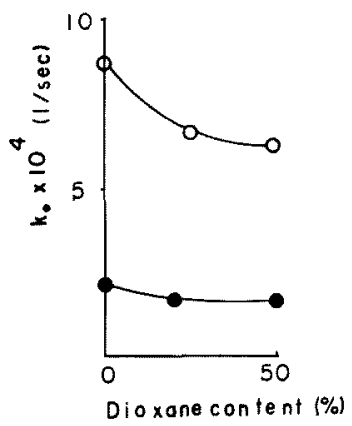

Fig. 4 Effect of dioxane content in DMSO solution on initial reaction rate constant $\left(k_{0}\right)$ at $60^{\circ} \mathrm{C}$

Odye I Odye II

らシオキサンの添加によって初速度は低下し均一系の限 界となるDMSO，ジオキサン（1：1）の場合の最高反 応量は，染料(1)に拈いては $15 \%$ ，染料（2）については $28 \%$ となて反応性は低下する。これは反応系の溶媒効 果の影響で特にPVAの水酸基が分子間水素結合等索起し， 反沁に活性な遊離の水酸基 ${ }^{8)}$ が少なくなったため加水分 
解との競争反応で加水分解の方が速く起ると考えられる。 比較のためイソプロピルアルコールと2-ィトキシ - 4フミノー6ークロル-1，3，5-トリアシンの反応をDMSO 溶液中及び DMSO-シオキサン（1：1）の泥合溶液中 でニュートラルレッドを指示薬として生成する塩酸を中 和滴定し加水分解量をさし引いて反应速度調心た結果， DMSO中で $k_{0}=2.5 \times 10^{-\mathrm{s}}(1 / \mathrm{sec})$ であり，DMSO ージオキサン ( $1: 1)$ 中では $k_{0}=0.83 \times 10^{-3}(1 / \mathrm{sec})$ でPVAの反応と融じようインプロピルフルコールの 水酸基が分子間水素結合を起こし反応が迤くなったもの と考えられる。

\section{2 不均一系反応}

実䟢の絨維のよらに非結晶領域が，結晶領域に囲まれ た場合，非晶領域の反応はどのようになるかを調べるた め㵶維状を保った状態で反応を行った。前項の結果から DMSOーシオキサン (1:1)の混合溶液を用いてPVA

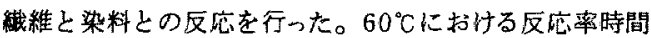
曲線を染料 (1) との反汒についてはFig. 5, 染料 (2)に対 してFig.6に示す。Fig.20均一系反応に比較して反结 性屾非常に低い。最高反论率媣料 (1) で 3\%, 染料 (2) で5\%である。さらに反応時間を長くすると反応率は逆に 低下した。均一系反応においても反応時間を 10 時間以 上にすると反応率の低下が諗められた。この原因は $\mathbf{H i}$

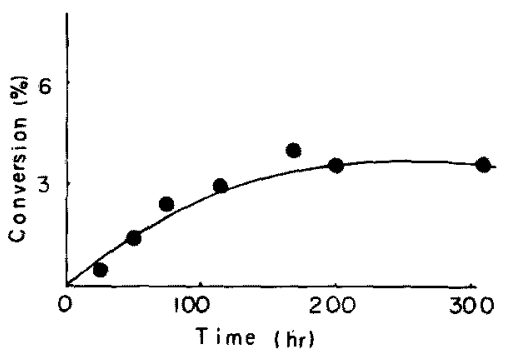

Fig. 5 Relation between reaction time and conversion in the reaction of PVA fiber with dye I at $60^{\circ} \mathrm{C}$.

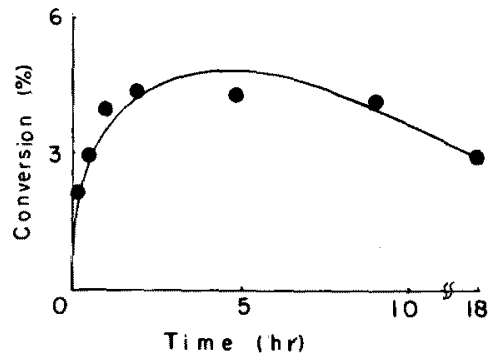

Fig. 6 Relation between reaction time and conversion in the reaction of PVA fiber with dye II at $60^{\circ} \mathrm{C}$. ldebrand ${ }^{0)}$ の指摘しているように次の副反応が起こる ためと考えられる。
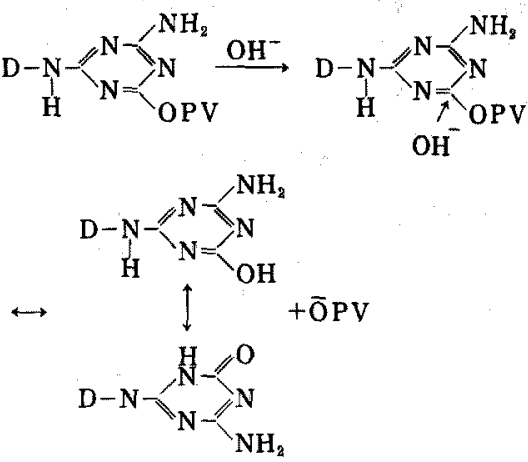

ここでD，PVはそれぞれ染料，PVAの残基を表わす。 不均一系反应に扔いて\&PVAの二次転移点 $\left(80^{\circ} \mathrm{C}\right)$ 以

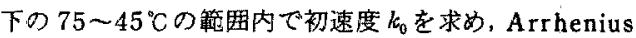
の式にあてはめると Fig.3の実験のようになりこれからら 活性化エネルギを求めると，染料(1)では $40 \mathrm{kcal} /$ $\mathrm{mol}$ ，染料 (2) では $38 \mathrm{kcal} / \mathrm{mol}$ が得られた。不均一 系反応においては染料の抬散性が反応の支配因子となる

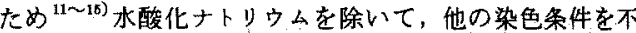
均一反応と同一にして染料 (2)のPVAフィルム中への

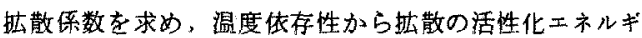
をFig.7より求めると $E=38 \mathrm{kcal} / \mathrm{mol}$ となり，前記

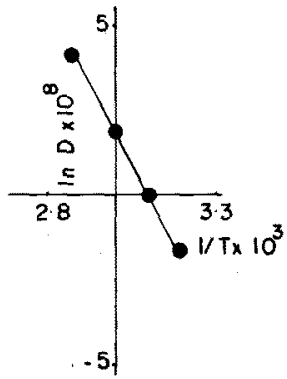

Fig. 7 Arrhenius plot of diffusion coefficient $(D)$ of dye II in neutral medium.

の活性化江ネルギとよく一致する。

一般の払散の活性化ェネルギに比較し，この值は非常 に大きい。これは通常の桩散の実験で用いられる染料濃 度はせいぜい $2 \mathrm{~g} / l$ 程度である。この場合には，反成性 を检討している条件は染料濃度が $50 \mathrm{~g} / \mathrm{l}$ と非常に大き く，染料が凝集して，非常に抬散が起こりにくいためで あるらと考えられる。G.E.Krichevskii " の央験にお いて，染料濃度の增大とともに拡散定数は低下すること 
が示されている。この染色系はDMSOージオキサン系 (非水溶媒中)でありテトラクロルエチレンからのポリ エステルの分散染色において，ガラス転䔟点以下の温度 領域で的 $70 \mathrm{kcal} / \mathrm{mol}$ 払散の活性化エネルギが報

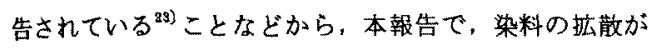
非常に革いと考えていることはさしつかえないであろう。 $\mathrm{NaOH}$ 含まない系ての染料の摭散举動が， $\mathrm{NaOH}$ 含んだ系に括いても同様に应散を行うと仮定する ${ }^{16)}$ と， 均一系と不均一系の反応性の美は固体緎維中の非晶領域 への染料の拡散が反応速度よりも遅いためと思われこの 染色系に枋いて不均一反忘では染料の払散が反応に重要 な要素となっている。

PVA 䋐維を熱処理して結晶化度を変えて染料 (2) と の反応を検討した結果をTable 1 に示す。表中の結晶化

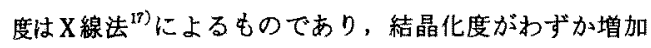
すれば，反応速度および最高反応量は低下する。これら はPVAのホルマール化反応の場合と同様であり ${ }^{17 〜 10) ， ~}$ 站散係数も結晶化度の上舁にしたがって急激に低下する。 初速度 $k_{0}$, 拡散䋆数 $(D)$, 最高反店率 $(M)$ と結晶化 度の関保を图示するとFig. 8 のよになった。この曲線 を延長すると結晶化度約 $52 \%$ の点で横軸と交差しこの 程度結晶化したものは染料の反応がほとんど認められな くなる。な招非晶部として $40 \%$ 以上存在しているにもか か⿰らず反它が起らないことは，PVA䋐維が湿式紡采 法によるため緎維表面が角筫化して染料の払散が起こり にくいこと ${ }^{20\rangle}$ と，办素結合のため ${ }^{10)}$ と考えられる。また 熱延伸により結晶の配向度を上げても同様であって, 配 向度の上昇にともなって $k_{0}$ および最高反度率とも低下し た。

以上の諸結果から，表面角質化，水素結合の增大が染 料の抬散を阻害することの主原と思われるから、これ らの表面構造を破壊するため濃硫酸処理 ${ }^{21)}$ と機械的破壊 を行なって実騟をした。前記試料No.4を50\%硫酸で米

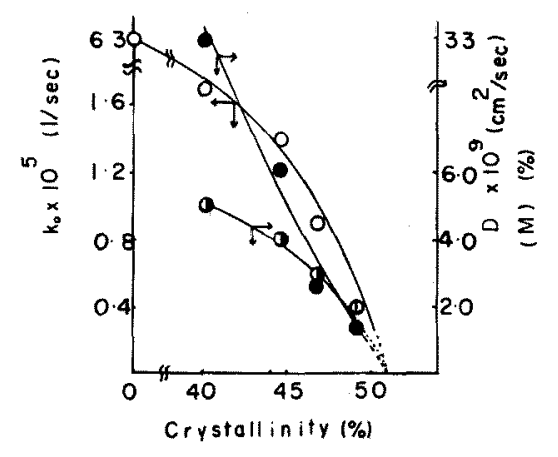

Fig. 8 Effect of crystallinity on max. amount of dye bonded $(M)$, initial reaction rate constant $\left(k_{0}\right)$ and diffusion coefficient (D) O initial rate constant $\left(k_{0}\right)$

- Diffusion coefficient $(D)$

- Max. amount of dye bonded $(M)$ at $60^{\circ} \mathrm{C}$.

水中’ $\left(0^{\circ} \mathrm{C}\right)$ て 30 秒好理した物と，フィブッル化装置 ${ }^{22)}$ を100回通した後の陚料について, 不均一采反応と同様 の反応条件で染料 (2) についての結果, 初期反応速度定 数, 最高反応率は Table 2 に示すよ5に，反応速度は 2.5〜3.0 倍となり反応率は $25 \%$ 上年した。これらの結

Table 2 Effects of chemical and mechanical treatments on dye bonded of PVA fiber at $60^{\circ} \mathrm{C}$

\begin{tabular}{ccc}
\hline Sample & $k_{0} \times 10^{5}(1 / \mathrm{sec})$ & Max. dye bonded $(\mathrm{mol} \%)$ \\
\hline 4 & 0.4 & 2.0 \\
8 & 1.3 & 2.5 \\
9 & 1.0 & 2.5 \\
\hline
\end{tabular}

Sample 8; Treated with $50 \% \mathrm{H}_{2} \mathrm{SO}_{4}\left(\right.$ Temp. $0{ }^{\circ} \mathrm{C}$, Time, $30 \mathrm{sec}$ )

Sample 9; Treated with fibrillating apparatus 100 times

Table 1 Effect of crystallinity and orientation of PVA chains on the maximum amount of dye bonded $(M)$, initial reaction rate constant $\left(k_{0}\right)$ and diffusion coefficient $(D)$ at $60^{\circ} \mathrm{C}$.

\begin{tabular}{cccccc}
\hline Sample & $\begin{array}{c}\text { crystallinity } \\
(\%)\end{array}$ & $\begin{array}{c}k_{0} \times 10^{5} \\
(1 / \mathrm{sec})\end{array}$ & $\begin{array}{c}D \times 10^{9} \\
\left(\mathrm{~cm}^{2} / \mathrm{sec}\right)\end{array}$ & $\begin{array}{c}M \\
(\mathrm{~mol} \%)\end{array}$ & $\begin{array}{c}\text { annealing temp. } \\
\left({ }^{\circ} \mathrm{C}\right)\end{array}$ \\
\hline 1 & 40.3 & 1.7 & 33 & 5.0 & - \\
2 & 44.8 & 1.4 & 6.0 & 4.0 & 140 \\
3 & 47.0 & 0.9 & 2.6 & 3.0 & 160 \\
4 & 49.3 & 0.4 & 1.5 & 2.0 & 180 \\
\hline \multicolumn{7}{r}{} & orientation (\%) & & & & draw ratio \\
\hline 5 & 82 & 1.1 & - & 3.0 & 0 \\
6 & 93 & 0.8 & - & 3.0 & 200 \\
7 & 95 & 0.6 & - & 2.0 & 400 \\
\hline
\end{tabular}




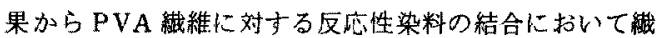
維表面の角質化，本素結合が反広を阻害する大きい因子 と考えられる。

\section{3. 結言}

PVA 瀻維に対する反応性染料の反応性を検討するた め, PVAの溶湾反応をPVAの非晶㖽域のモデル反芯 と考六，反忘系均一反沈加不均一反応へと変化させ て，非晶領域の状態の変化にしたがって反応性がいかに 異なるかを研究した。そのため二種類の染料を合成し， この染料と PVAの均一系抬よび不均一系反応を検討 L つぎの結果を得た。

a）トリアジン基に電子吸収性の大きい基が存在すれ ば反度率は上昇する。

b) PVAの不均一系反応恃均一系反応に比較して非 常に反応性が悪い。染料濃度の非常に大きな系であ るため，染料の应散係数が染料の凝集したため非常 に大きく，反他は染料の抬散が重要な要素である。 長時間反応させると反応生成物が分離するため反石 融は極大値をむ。

c) PVAの不均一反応は染料のPVA中での拡散が 重要な要㯝になっており，結晶化度 $52 \%$ 以上では反 们が起こらない。これは織維表面の解筫化，分子間 の水素結合が主な原因上考えられる。これらを破壊 すれば反応率を向上させることができる。

\section{文献}

1) Beech, Walter F.: "Fiber-Reactive Dyes" Logoes: London, Eng1. (1971)

2) K.R.F.Cockett, I.D.Rattee, C.B.Stev- ens ; J. Soe. Dyers Colur., 85, $113(1969)$

3) 簙 義人, 河原共采, 桜田一郎; 高分子学会年次 大会講演要旨集”, p. 186, 187 (1971)

4) 後藤共子，辰野正满；日化会誌，1514（1972)

5）後藤共子，曼野正满；高分子化学，29，515 (1972)

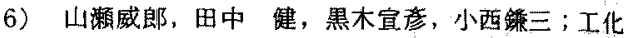
$67,110(1964)$

7）大矢精治，山岸康秀；瀻学誌，28，29（1972）

8）関户 実，棵田全三；染色工業，13，103(1965)

9) D.Hildebrand ; Textil-Praxis, 26, 564 (1971)

10) S.P.Rowland, E.J.Roberts ; J. Polym. Sei., A-1., 10, 867 (1972)

11) P.V.Danckwerts ; Trans. Faraday Soc., 46 , 300 (1950)

12) H.H.Summer, T.Vickerstaff ; Melliand Textilber., 42, 1161 (1961)

13) T.Vickerstaff; J. Soc. Dyers Colour., 73 , 237 (1957)

14) G.E.Krichevskii, I.M.Movshovich ; Text. Res. J., 40,793 (1970)

15) J.Shore ; J. Soc. Dyers Colour., 85, 14 (1969)

16) J.M.Goppel；Appl. Sci.Res., A1, 18 (1947)

17) 桜田一郎，中村份史; 高分子化学, 8,539 (1951)

18）吉岡義英，長野正満；高分子化学，9，36（1952）

19）川濑裕司；蟣学誌，28，69(1972)

20）川上博，川嶋憲治，三好明；䄉学誌，24， $543(1968)$

21）曾根健夫, 山崎 隆、相宅省吾; 織学誌, 28, 318 (1972)

22）長野正満，知野 勉; 高分子化学, 27,770 (1970)

23）小林立子，本村洋美，森田全三；第 15 回染色化 学䞑論会, p. 40 (1973) 